\title{
SEPT5 wt Allele
}

National Cancer Institute

\section{Source}

National Cancer Institute. SEPT5 wt Allele. NCI Thesaurus. Code C97728.

Human SEPT 5 wild-type allele is located in the vicinity of $22 q 11.21$ and is approximately $10 \mathrm{~kb}$ in length. This allele, which encodes septin-5 protein, is involved in cytokinesis. A chromosomal translocation $\mathrm{t}(11 ; 22)(\mathrm{q} 23 ; \mathrm{q} 11.2)$ of this gene and the MLL gene is associated with acute myeloid leukemia. 